\title{
Competitive strategies among Ontario farms marketing direct to consumers
}

\author{
Eric T. Micheels ${ }^{1 *}$ and Andreas Boecker ${ }^{2}$
}

\author{
* Correspondence: \\ eric.micheels@usask.ca \\ ${ }^{1}$ Department of Agricultural and \\ Resource Economics, University of \\ Saskatchewan, 51 Campus Drive, \\ Saskatoon, SK S7N 5A8, Canada \\ Full list of author information is \\ available at the end of the article
}

\begin{abstract}
This paper examines the importance of two resources, namely a market orientation and an entrepreneurial orientation, in new product development and satisfaction with firm performance among direct and alternative marketers. Using a partial least squares structural equation model and data from a 2013 survey, this paper models the effect of a market orientation and entrepreneurial orientation on satisfaction with current performance and expected future performance for agricultural firms in Ontario, Canada. Our results show that a market orientation and entrepreneurial orientation are important factors in determining rates of product and marketing innovations among farm-based agribusinesses. These findings further demonstrate that a market orientation is a powerful resource as it enables firms to become aware of opportunities to provide superior value for consumers, especially when operating in non-traditional markets.
\end{abstract}

Keywords: Direct marketing, Entrepreneurial orientation, Market orientation, Marketing innovation, Product innovation

JEL codes: D22, D83, M31, M37

\section{Background}

The number of farmers' markets has been growing across Canada in the past decade (Dukeshire et al. 2014). A recent study of consumers at farmers' markets in Toronto, Ontario, found that consumers use farmers' markets not only to fulfil specific grocery needs but also to support local agricultural firms (Dodds et al. 2013). Hence, sales in Ontario farmers' markets by primary producers were estimated to be between $\$ 385$ million and \$577 million annually in 2010, up from an estimated \$73 million in 1999 (Cummings et al. 1999; Regional Analytics and Planscape 2011). Innovative and entrepreneurial agricultural firms may aspire to improve performance by marketing their production in a manner that takes advantage of these trends. For example, farms in Ontario market their production direct to consumers through not only farmers' markets but also on-farm markets and roadside stands, community-supported agriculture and boxing schemes, and on- and off-farm events. It is estimated that these additional outlets account for $25 \%$ of direct sales while farmers' markets account for $75 \%$ (Schumilas 2010). Given the increased use of direct and alternative marketing channels in Ontario, a greater understanding of the factors that drive current and expected success within these alternative marketing channels seems warranted.

(c) The Author(s). 2017 Open Access This article is distributed under the terms of the Creative Commons Attribution 4.0 International License (http://creativecommons.org/licenses/by/4.0/), which permits unrestricted use, distribution, and reproduction in any medium, provided you give appropriate credit to the original author(s) and the source, provide a link to the Creative Commons license, and indicate if changes were made. 
The move to direct and alternative markets may signal that firms are not satisfied with current levels of performance achieved through more traditional channels and are therefore searching for other means to improve performance (Levinthal and March 1993; Mount 2012). In the search for new profit opportunities, firms may modify product offerings or production practices to differentiate their production from that of other firms. For smaller firms, innovations in how the product is marketed may be more scaleappropriate and more likely to lead to improved performance (Moser et al. 2011). However, as the number of farmers' markets has increased (Dukeshire et al. 2014) along with the number of farms selling a portion of their production through farmers markets (Uematsu and Mishra 2011), these farm businesses need to further differentiate themselves from competition for continued success. In this sense, farm-based businesses who have moved into direct and alternative marketing channels may now face greater levels of competition compared to early adopters within these channels. This would suggest that the resources and capabilities that have been important in determining success in other small businesses may now be important in determining success of farm-based direct marketing ventures. However, as these farm businesses often start out as traditional farms, the level of human and relational capital that has been invested in developing resources to identify new opportunities in product or market spaces may be rather limited. As these markets become increasingly competitive, firms that are more quickly able to identify and respond to market needs may have improved performance outcomes.

Research across different industries has shown that firms that are aware of opportunities and are able to respond to these opportunities are able to improve performance (Renko et al. 2009; Rauch et al. 2009). However, since firms and their resource endowment, including managerial skill sets, are heterogeneous, firms may develop and employ diverse strategies in the search for profit. For research in this area, this raises the need for addressing the identification of critical resources-managerial skills on the one hand and adaptive strategies on the other-as well as determining the interrelations among them. In the managerial research literature, a number of constructs have been developed and applied empirically to capture the managerial resources that facilitate efficient responses to change.

The purpose of this paper is to examine how two of these constructs, market orientation and entrepreneurial orientation, affect the focus of innovation on the farm and the satisfaction with current and expected performance. Recent work in this area examined the role of these constructs and other factors on new product success and the number of marketing channels utilized by direct marketers (Mirzaei et al., 2016). Slater and Narver (1995, pp 67) define market orientation as "the culture that (1) places the highest priority on the profitable creation and maintenance of superior customer value while considering the interests of other key stakeholders; and (2) provides norms for behaviour regarding the organizational development of and responsiveness to market information." While cultures such as this are important, the delivery of superior value to the customer requires action on the part of the firm. That action may stem from an entrepreneurial orientation, which Lumpkin and Dess (1996, pp. 136) define as "the processes, practices, and decision-making activities that lead to new entry." The entry described may be entry into new marketing channels or new product markets and may be a response to increasing consumer demand for locally produced products (Adams and Adams 2011; Hu et al. 2012; Gracia 2012; Kim et al. 2014).

We developed a survey that measures market orientation, entrepreneurial orientation, and product and marketing innovations of farmers in Ontario over the past 3 years. 
Product innovations we examine are new products and new packaging of existing products, while marketing innovations include the use of new marketing channels and new promotional strategies as well as changes in pricing. Using the data from the survey, we build a partial least squares structural equation model (PLS-SEM) to determine how these latent variables are interrelated and affect expected future performance and satisfaction with current performance. This work contributes to the literature on performance analysis of agricultural firms marketing their production through direct and alternative market channels by simultaneously examining critical managerial skills and adaptive strategies in their impact on performance.

In the sections that follow, we review the prior literature surrounding direct marketing, market orientation, and entrepreneurial orientation. We use this literature to develop hypotheses and a structural model that will be used to test the hypotheses. The "Methods" section outlines the data and methods used in the study. The "Results and discussion" section describes the results of the structural equation model used to test the hypotheses. Finally, the paper concludes with a discussion of the results, the implications of these results to managers and other stakeholders, and an outlook on further research that would address some of the limitations of this study.

\section{Methods}

\section{Previous literature and model development}

Considerable research on consumer preferences for local food and the drivers of increased demand has been conducted (Adams and Adams 2011; Cranfield et al. 2012; Feldmann and Hamm 2015; Thilmany et al. 2008; Weatherell et al. 2003), but research on the manner by which firms respond to and benefit from meeting these needs is somewhat limited. In a recent study, Low and Vogel (2011) find that local food marketers in the USA utilize both direct-to-consumer outlets (farmers markets, roadside stands, etc.) as well as intermediated outlets (direct-to-grocer, direct-to-distributor, etc.), and the value of production marketed though these alternative channels has been increasing since 1992. Low and Vogel (2011) further find that while all local food marketers utilize direct-to-consumer channels, farms with sales of $\$ 250,000$ or more make greater use of intermediated channels. This is supported by the finding of Sun et al. (2014) that larger wineries in emerging wine regions in the USA market a larger proportion of their production through intermediated channels.

A key characteristic of these alternative marketing channels is that the primacy of the information that is shared between market participants leads to highly relational markets. Research within New Zealand farmers' markets, for example, found that sellers place considerable value on the ability to try out new product formulations or packaging redesigns and quickly gauge customer feedback (Guthrie et al. 2006). Although agricultural firms involved in direct marketing may not have vast innovation budgets that high-tech firms possess, Rosenbusch et al. (2011) found that even for smaller, resource-scarce firms, the benefits of differentiation, such as increased loyalty, price premiums, and entry barriers, outweighed the costs and the risks involved in the innovative activity.

While the studies referenced above provide valuable information on specific aspects and trends in local food marketing, they do not investigate how managerial resources affect innovation choices and performance. In the remainder of this section, we therefore present a literature review for each of the two managerial resource constructs most 
relevant to this research, market orientation (MO) and entrepreneurial orientation (EO), from which hypotheses are derived and a structural equation model developed. A challenge for this literature review, however, was that a number of studies have used scales that were similar but not necessarily based on the original scales by Slater and Narver (1995) and by Lumpkin and Dess (1996) to measure market and/or entrepreneurial orientations. In some studies, the differentiation between the two constructs has thus not been straightforward but required interpretation.

\section{Market orientation}

While small- and medium-sized enterprises (SMEs) in food production may rely on innovativeness and new product development to meet consumer needs (Trienekens et al. 2008; Gellynck et al. 2012), the success of this strategy depends on the firm's ability to become aware of and respond to these needs before the competition. For example, Webb et al. (2010) find that market-oriented firms are better equipped to recognize opportunities and to capitalize on them through innovation. This ability stems from the marketoriented firm's capability in generating and acquiring market-focused intelligence based on interactions with lead customers in order to provide the organization with the information needed to develop new products that are valued by the market (Slater and Narver 2000). Moreover, it has been shown by Gunday et al. (2011) that innovation performance (the ability to develop and introduce new products) improves market performance, as measured through sales or market share.

Market-oriented firms have been shown to be proactive in developing new products and services to serve their markets (Cambra-Fierro et al. 2011; Nasution et al. 2011; Beck et al. 2011). Firms that are able to integrate market awareness and appropriate responses into innovation programmes are able to achieve stronger linkages with customer value (Nasution et al. 2011). In a study of family firms in the Netherlands and Belgium, Beck et al. (2011) find that the type of market orientation (responsive, proactive, emerging) fully mediated the level of innovation that family firms undertook, even when controlling for other factors. Moreover, Tan and Liu (2014) find that firms with a responsive market orientation are expected to be successful in innovation strategies that build on current customers and capabilities. Lamore et al. (2013) suggest that firms with a proactive market orientation succeed by identifying unmet and unarticulated market needs while firms with a more responsive market orientation succeed when they are able to meet current customers already expressed needs.

It may seem that agricultural firms who market through direct and alternative markets are not applicable in this literature. While agricultural firms may bear little resemblance to high-tech firms or others who seem to be leaders in innovation, these firms are innovators according to the definition of innovation by Nelson and Winter (1982) who define innovation as a change in routine. As much of agriculture consists of routine (i.e. seeding, harvest, marketing) even incremental changes in the acquisition of inputs, the nature of production or the manner in which firms market the product could be seen as an innovation in this sense. However, in order for these changes to be successful, these firms must understand the nature of their current and prospective customers as well as the strengths and weaknesses of current and potential competitors. Based on the findings from previous conceptual and empirical studies presented above, we derive the following hypotheses: 
H1: An increase in the market orientation of the firm is associated with an increase in the level of product innovations within the firm.

$\mathrm{H} 2$ : An increase in the market orientation of the firm is associated with an increase in the level of marketing innovations within the firm.

H3: An increase in the market orientation of the firm is associated with higher levels of satisfaction with current performance.

H4: An increase in the market orientation of the firm is associated with an increase in the expectations of future performance.

\section{Entrepreneurial orientation}

A body of literature has also examined how entrepreneurial orientation in management can improve firm performance. Pérez-Luño et al. (2011) find that entrepreneurial firms, particularly those who are proactive and are willing to take on additional risk, are more likely to generate new ideas and processes as well as adopt successful ideas that other firms have implemented. Evidence of successful imitation strategies has been found directly in some studies (Lee et al. 2000; Lee and Zhou 2012), as well as in an attempt to leverage the competitive aggressiveness of entrepreneurial firms (Lumpkin and Dess 1996; Wang 2008; Rhee et al. 2010).

Using measures from Covin and Slevin (1989) and Wiklund (1999), Grande et al. (2011) find that farm firms involved in traditional agricultural production (as well as value-added processing who are more entrepreneurial) have better performance than firms who are not as entrepreneurial. Moreover, Knudson et al. (2004) suggest that entrepreneurial innovators, such as organic food farms, are determined to innovate and bring new products to market in order to boost firm performance. In addition, de Lauwere (2005) finds that more entrepreneurial farmers, referred to as social farmers and new growers in the study, had more optimistic expectations for future performance as well as higher actual farm incomes.

Grande et al. (2011) develop a model of farm performance with firm size, the use of networks, the financial position of the firm, and the entrepreneurial orientation of the firm as explanatory variables. Their results show that firms who score higher on the entrepreneurial orientation scale also achieve higher profits and more aggressive sales growth measures. Nasution et al. (2011) find evidence in a study of hotel managers that firms who score higher on proactiveness and risk-taking scales are more innovative in terms of product and process innovations developed. Similarly, Tajeddini (2010) finds that hotels with an entrepreneurial orientation are more innovative and are better able to meet goals relating to market and financial performance. These results are similar to studies in other industries, and the positive effect on profit and sales may be caused by the ability of these firms to recognize opportunities in the market and be proactive in their response to these opportunities (Lumpkin and Dess 2001; Moreno and Casillas 2008; Rauch et al. 2009).

Given the increased level of competition at farmers' markets (Beckie et al. 2012), Boehlje and Bröring (2011) suggest that first-mover advantages in new markets may create entry barriers for subsequent firms as leading firms are able to develop valuable relationships with key customers. However, given the capital intensive nature of agricultural production, firms may be reluctant to invest in new products or processes. This reluctance may be further embedded due to the perceived lack of dynamism in agriculture. 
However, findings by Wiklund and Shepherd (2005) suggest that an EO could increase performance regardless of capital availability or market dynamism. From the above presented findings and considerations, we derive the following hypotheses:

$\mathrm{H} 5$ : An increase in the entrepreneurial orientation of the firm is associated with an increase in the level of product innovations within the firm.

H6: An increase in the entrepreneurial orientation of the firm is associated with an increase in the level of marketing innovations within the firm.

H7: An increase in the entrepreneurial orientation of the firm is associated with an increase in the level of satisfaction with current performance.

H8: An increase in the entrepreneurial orientation of the firm is associated with an increase in the level of expected performance.

\section{Innovation}

Previous studies have shown that innovativeness mediates the link between a market orientation and firm performance (Han et al. 1998; Tajeddini et al. 2006; Hong et al. 2013). While awareness of market conditions and the willingness to take on additional risk are important success factors, firms must initiate and implement appropriate changes in routines to improve firm performance. Research has shown that the use of market information is a critical success factor in the complex internal decisions of agribusiness companies to select innovation projects for funding (Roucan-Kane et al. 2011). Köhler et al. (2012) find that greater use of market-driven search increases the rate of success when firms imitate product or process innovations of rival firms. As firms that market their production through direct and alternative channels have close contact with all customers, we would expect that they would have greater access to relevant market information, e.g. through customer surveys and product trials, and would thus be in a better position to react to this information and improve performance. Hence, we propose the following hypotheses:

H9a: An increase in the level of product innovations within the past three years is associated with an increase in satisfaction with current performance.

H9b: An increase in the level of product innovations within the past three years is associated with an increase in expectations regarding future performance.

Researchers have developed various typologies of innovation (Garcia and Calantone 2002; Rowley et al. 2011). Innovations can be thought of along product and technological lines or according to how radical the change is. For example, the innovation undertaken by a firm could be new to the world or it could be an adoption of an existing innovation with the change being new to the firm (i.e. Garcia and Calantone 2002). The innovation may also encompass a change in how the products are marketed (Boehlje et al. 1995; Boehlje 2002).

Marketing innovations entail the identification and development of new markets or ways of marketing. Regardless of whether the innovation is related to new or existing products, finding the right consumers for these products is also an important capability. Di Stefano et al. (2012), using a meta-analysis of innovation studies, find evidence that matching market needs to new products is an important capability that may ultimately 
ensure the success of the new product. Recent studies have shown that marketing innovations (measured as changes in product distribution, pricing, and promotion of products) significantly contribute to satisfaction with performance (Camisón and Villar-López 2011; Gunday et al. 2011). Ngo and O'Cass (2012) find evidence that suggests that a firm's marketing capability and their innovation- and customer-related performance are significantly related to the firm's market orientation. Expecting that these relationships would also hold for farms selling through direct and alternative channels in Ontario, we propose the following hypotheses:

H10a: An increase in the level of marketing innovations within the past three years is associated with an increase in satisfaction with current performance.

H10b: An increase in the level of marketing innovations within the past three years is associated with an increase in expectations regarding future performance.

Given the previously discussed literature and the hypotheses presented, we model the firm's product and marketing channel innovations as a function of their awareness of customer needs and competitor actions (i.e. their market orientation) as well as their willingness to be proactive and take calculated risks in response to these needs (i.e. their entrepreneurial orientation). In addition, key farm characteristics, such as farm size and farming experience need to be controlled for, as these have been found to influence the choice of farmers' income diversification activities (Barbieri and Mahoney 2009). From this background, we develop a structural model of managerial orientation, innovation strategy, and firm performance to be applied to data from Ontario farms that market through direct and alternative channels (Fig. 1).

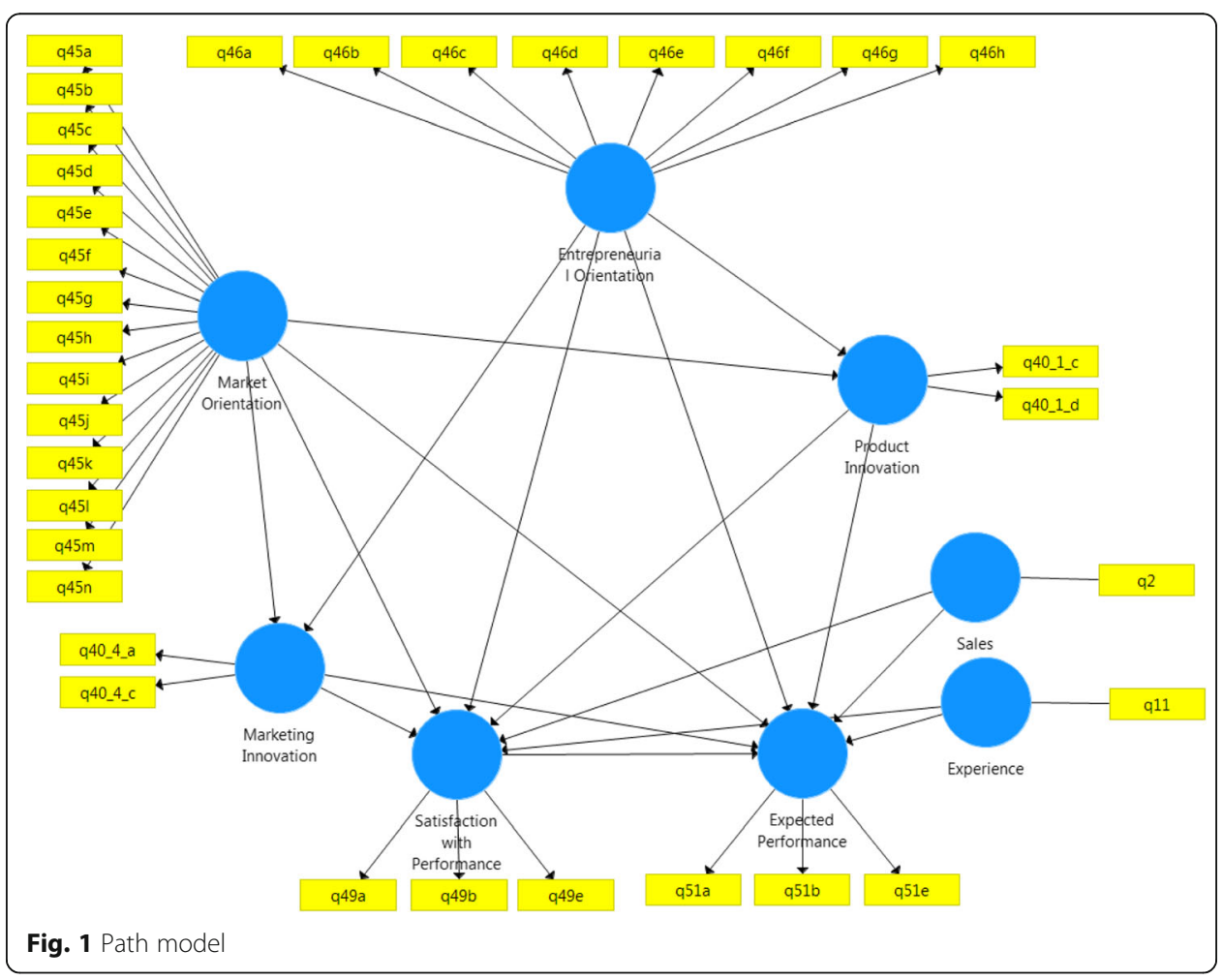




\section{Survey methods}

After developing a questionnaire in consultation with members from Agriculture and Agri-Food Canada, it was administered by Ipsos Agriculture and Animal Health in April and May of 2013. The questionnaire consisted of six sections: demographics, sources of farm income, use of various marketing channels, knowledge of production and marketing-related costs, measurement of the firm's market orientation and entrepreneurial orientation, and satisfaction with financial performance indicators.

To measure the market orientation of the respondents, we modified the original Narver and Slater's (1990) scale to fit the context of the Ontario agri-food industry. This scale has been used in previous studies (Langerak 2003; Farrell et al. 2008; Nasution et al. 2011; Cheng and Krumwiede 2012) and its 14 items relate to three inter-related concepts: a customer orientation, a competitor orientation, and inter-functional coordination. The individual items in the scale measure a respondent's level of agreement with perspectives relating to the firms' collection of information on customer needs and competitor responses (see Appendix 1). After adjusting for the direction of an item statement (agreement with a negative), higher scores indicate greater market orientation.

The entrepreneurial orientation scale was first developed by Covin and Slevin (1989) and also consists of three inter-related concepts: proactiveness, innovativeness, and risk-taking. It has been primarily used in previous studies that examined innovativeness and firm performance (Keh et al. 2007; Li et al. 2009; Hansen et al. 2011). For the individual items, respondents were given two anchors which attempted to maximize differences in firm posture and strategy for each of the eight items in total (see Appendix 1). Again, after adjusting for direction of a statement, a higher score indicates greater entrepreneurial orientation. As both scales were initially developed for non-agricultural contexts, slight modifications were made to fit the targeted research population.

Innovation can take several forms, ranging from new product development and new packaging and processing to changes in marketing and management practices or organizational structure and processes (Lambrecht et al. 2015). For the purposes of this study, we focus on two areas of change within direct and alternative markets: product innovations (new products and new packaging) and marketing innovations (new channels and changes in marketing communications). We measure these in an incremental/ radical innovation framework similar to previous work by Dewar (1986) and Song and Thieme (2009). Therefore, the intensity of innovation was measured for each item on an ordinal scale with three levels: not at all, to some extent, and to a great extent (Table 5).

While studies have examined just how a market orientation and an entrepreneurial orientation influence innovative activity, we were also interested in how changes in these factors were associated with changes in two subjective measures of firm performance. We asked respondents to report their satisfaction with current performance as well as their expectations of future performance (the next 5 years) (Fig. 2). As detailed in Appendix 2, items focused only on financial indicators and included net income, sales, and cash-flow. This method is in line with other recent studies that have asked respondents to rate their satisfaction with certain levels of performance or to compare different aspects of performance to main competitors (Brik et al. 2011; Yannopoulos et al. 2012). Objective measures of performance would not have been obtainable as private family businesses are generally unwilling to share confidential financial data, even in anonymous settings (Shoemaker et al. 2002), and no secondary data exists 


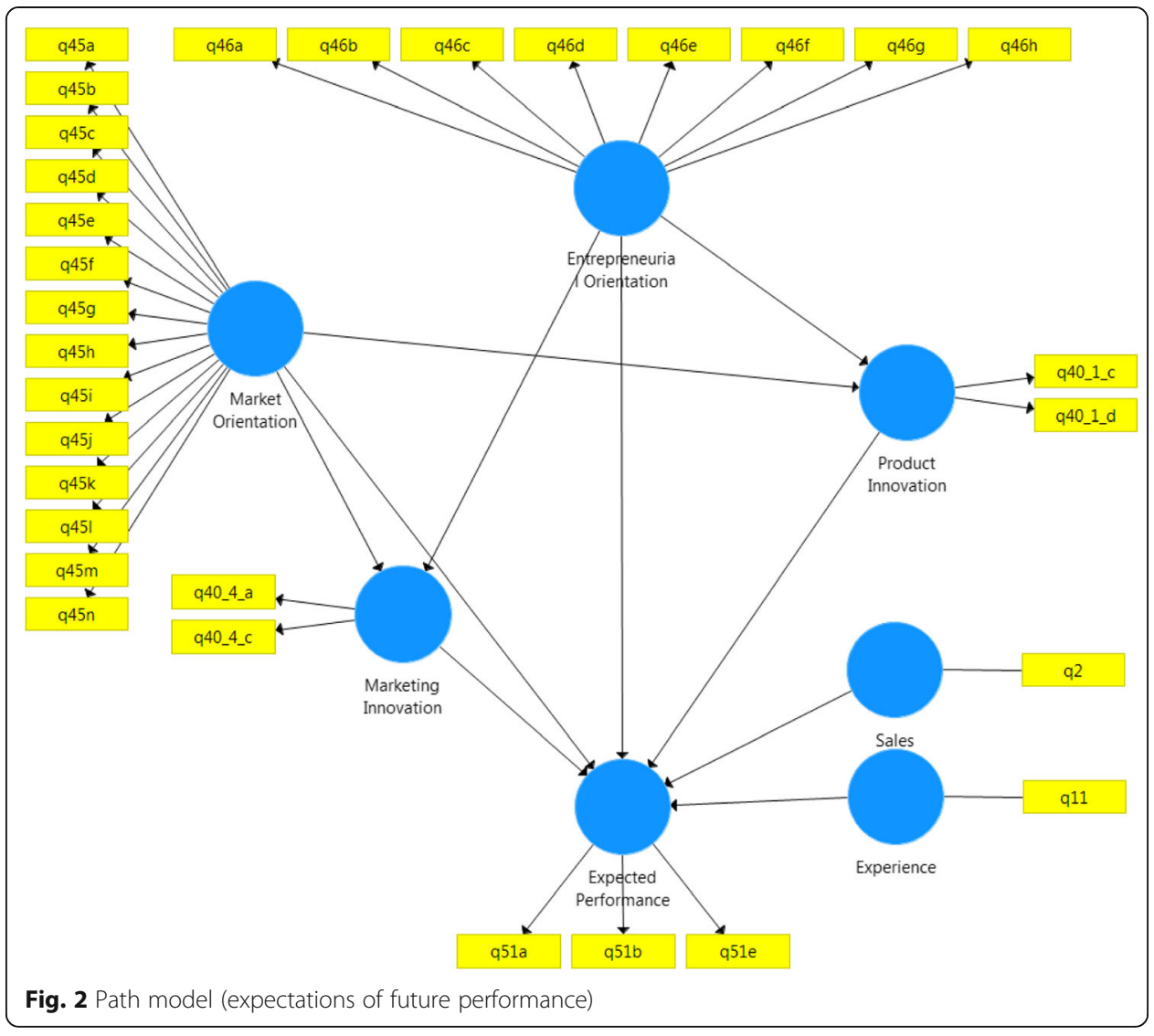

that also includes measures for market orientation and entrepreneurial orientation. For current performance, the scale anchor points were 'very dissatisfied' (1) and 'very satisfied' (7), and 'will deteriorate significantly' (1) and 'will improve significantly' (7) for expected future performance. Recently, Mahto et al. (2010) examined how family interaction and identification with the family business are significantly related to satisfaction with performance of the family business. As most farm businesses are family businesses, the use of satisfaction with performance (rather than actual performance) may be an adequate workaround, even if satisfaction with similar levels of performance may differ across respondents.

Furthermore, while objective measures of performance such as sales and profit levels may be preferred, studies have shown a strong correlation between subjective and objective measures of performance (Dess and Robinson 1984; Richard et al. 2009; Dawes 1999; Wall et al. 2004). For example, Wall et al. (2004) show that in a sample of UK manufacturing and service sector firms, subjective performance measures demonstrate both convergent and discriminant validity, meaning there is a high correlation between parallel subjective and objective measures and little correlation between nonparallel subjective and objective measures.

Ipsos Agriculture and Animal Health emailed the questionnaires to a proprietary panel of Ontario producers. Specific quotas of farm types (dairy, beef, crops, etc.) were used to limit over and under sampling of specific groups of the diverse Ontario farm population. This panel of farmers has been used in other agricultural research (e.g. Nadella et al. 2014). Respondents who completed the survey received \$20 CAD for 
their time. An email containing a link to the survey was sent to 10,406 unique email addresses that are included in a proprietary database by IPSOS Animal Health. On average, surveys were completed in $34 \mathrm{~min}$ and a total of 799 respondents ${ }^{1}$ attempted the survey and 405 respondents completed the survey. Based on the 405 completed questionnaires, this amounts to a $3.9 \%$ response rate. ${ }^{2}$ This study uses a sub-sample of 126 respondents who have been active in farm direct and alternative marketing.

\section{Description of respondents}

Table 1 shows the distribution across annual gross farm sales for the full sample, the study sample of 126 farmers involved in direct and alternative marketing, and the 2011 agricultural census for Ontario. While farms with $\$ 99,999$ CAD in sales or less are underrepresented in the full sample compared to census figures, large farms with annual gross sales of $\$ 500,000$ or more are similarly over represented. However, it has to be pointed out that Ontario gross farm receipts in 2012-the year of measurement in our survey-were more than $20 \%$ above those of 2010 - the year of measurement of the census (OMAFRA, 2014). Hence, the bias towards larger operations in our full sample is likely exaggerated. Although the size distribution of the study sample is generally more in line with the census figures, representativeness cannot be inferred. Previous observations that it is mostly small operations that market directly to consumers are, however, confirmed by $56 \%$ of study sample having annual gross sales below $\$ 100,000$, compared to $40 \%$ in the full sample.

The respondents in the study sample are key decision makers on their farms (Table 2). A majority of the respondents in the sample have final say in operational (54.8\%), financial (52.4\%), and marketing (54.8\%) decisions, and over $40 \%$ of respondents share decisionmaking in these areas with somebody else on the farm. We also asked respondents about the life cycle stage their farm is at. Ten respondents $(8 \%)$ self-reported to be in the "getting my farm operation established" category. The vast majority placed their operation in one of two "established" categories: 54 (43\%) as "maintaining the operation at a steady level" and 48 (38\%) "expanding the operation." The remaining 14 respondents (11\%) stated that they were beginning to scale down or planning to sell their operation in the near future.

The respondents in our sample report using a portfolio of methods to market their production (Table 3). A majority of them report to market part of their production wholesale (71\%). For these operations, selling wholesale on average accounts for $63 \%$ of gross sales and for $51 \%$ of net family income.

Table 1 Gross sales of survey respondents in full and study sample compared to census

\begin{tabular}{|c|c|c|c|c|c|}
\hline \multirow[b]{2}{*}{ Annual gross sales brackets } & \multicolumn{2}{|c|}{ Full sample $(n=405)$} & \multicolumn{2}{|c|}{ Study sample $(n=126)$} & \multirow{2}{*}{$\begin{array}{l}\text { Census } \\
\text { Percent }\end{array}$} \\
\hline & Count & Percent & Count & Percent & \\
\hline$\$ 10,000$ to $\$ 24,999$ & 62 & 15.3 & 35 & 27.8 & 17.5 \\
\hline$\$ 25,000$ to $\$ 49,999$ & 53 & 13.1 & 18 & 14.3 & 12.9 \\
\hline$\$ 50,000$ to $\$ 99,999$ & 44 & 10.9 & 17 & 13.5 & 11.9 \\
\hline$\$ 100,000$ to $\$ 249,999$ & 74 & 18.3 & 20 & 15.9 & 13.4 \\
\hline$\$ 250,000$ to $\$ 499,999$ & 66 & 16.3 & 19 & 15.1 & 9.8 \\
\hline$\$ 500,000$ to $\$ 999,999$ & 52 & 12.8 & 4 & 3.2 & 6.3 \\
\hline$\$ 1$ million and over & 54 & 13.3 & 13 & 10.3 & 4.5 \\
\hline
\end{tabular}

${ }^{a} 2011$ federal agricultural census results for the province of Ontario 
Table 2 Frequency of decision-making authority among respondents $(N=126)$

\begin{tabular}{|c|c|c|c|}
\hline \multirow[b]{2}{*}{ Decision type } & \multicolumn{3}{|c|}{ Delegation of decision-making } \\
\hline & $\begin{array}{l}\text { I have the final say in } \\
\text { all decisions }\end{array}$ & $\begin{array}{l}\text { I share decision-making } \\
\text { with someone else }\end{array}$ & $\begin{array}{l}\text { I have some input but ultimately } \\
\text { leave decisions to someone else }\end{array}$ \\
\hline $\begin{array}{l}\text { Overall operational and } \\
\text { production decisions }\end{array}$ & $71(54.8 \%)$ & $53(42.1 \%)$ & $2(1.6 \%)$ \\
\hline $\begin{array}{l}\text { Financial management } \\
\text { decisions }\end{array}$ & $66(52.4 \%)$ & $60(47.6 \%)$ & $0(0.0 \%)$ \\
\hline Marketing decisions & $69(54.8 \%)$ & $54(42.9 \%)$ & $3(2.4 \%)$ \\
\hline
\end{tabular}

More specifically, 118 respondents (94\%) in the sample report they market direct to consumers through which these operations generate about one third of their gross farm sales and net farm income. Forty-one respondents (33\%) report being engaged in other forms of alternative marketing, such as selling to restaurants, independent grocers, or other institutions, thus generating one fifth of sales and net income. On average, the 126 operations in the sample sell through two specific types of direct or alternative sales outlets (Table 4), most commonly through roadside and farm gate stands (45\%), followed by farmers' markets, on-farm markets, and online shops (each with $24 \%$ ).

Overall, it appears that respondents have engaged less often in product and packaging innovation than in marketing channel and communication innovation during the past 3 years. This may indicate that investing in marketing innovations comprises less risk than investing in product innovations relative to the corresponding benefits. In regard to the control variables, Table 1 had already indicated lightly right-skewed distribution across the seven gross farm sales categories so that the median is 1 below the midpoint category. As expected, the study sample exhibits a large range of years of farming experience, i.e. from 3 to 55 years (Table 5).

\section{Results and discussion}

As the key variables in our proposed model are unobservable (i.e. market orientation, entrepreneurial orientation), we must measure these using multiple items from the survey. However, we first must ensure that the measurement items used in our sample are appropriate; therefore, a reliability analysis was conducted to ensure that the measurement scales used in the study exhibited construct validity and were consistent with previous studies. Reliability and validity tests for the scales indicate that they are sufficient as Cronbach alpha (Cronbach 1951) statistics are all relatively high and the average variance extracted (AVE) for most of the scales is above $0.50 .^{3}$ Cronbach

Table 3 Marketing methods among respondents $(N=126)$

\begin{tabular}{lllll}
\hline Marketing activity & Yes & No & Share of gross sales & $\begin{array}{l}\text { Share of net } \\
\text { family income }\end{array}$ \\
\hline Marketing farm commodities wholesale & $89(70.6 \%)$ & $37(29.4 \%)$ & $63.3 \%$ & $50.6 \%$ \\
$\begin{array}{l}\text { Marketing farm-fresh products or process } \\
\text { products directly to consumers }\end{array}$ & $118(93.7 \%)$ & $8(6.3 \%)$ & $34.3 \%$ & $33.2 \%$ \\
$\begin{array}{l}\text { Marketing farm-fresh products or processed } \\
\text { products directly to restaurants, institutions, } \\
\text { or local/independent retailers }\end{array}$ & $41(32.5 \%)$ & $85(67.5 \%)$ & $21.5 \%$ & $20.2 \%$ \\
\begin{tabular}{l} 
Agri-tourism \\
\hline
\end{tabular} & $14(11.1 \%)$ & $112(88.9 \%)$ & $13.6 \%$ & $8.9 \%$ \\
\hline
\end{tabular}

${ }^{a}$ Average shares reported for those respondents engaged in specific marketing activity; hence, reported percentage figures add up to more than $100 \%$ 
Table 4 Marketing channels used in 2012

\begin{tabular}{lll}
\hline Marketing channel & Yes & No \\
\hline Roadside or farm-gate stand & 57 & 69 \\
On-farm market, café, or restaurant & 30 & 96 \\
Farmers' market & 30 & 96 \\
Online shop & 30 & 96 \\
Events, on- or off-farm & 27 & 99 \\
Restaurant & 26 & 100 \\
Independent grocer & 24 & 102 \\
100 mile markets or similar & 12 & 114 \\
Institutions (schools, hospitals) & 11 & 115 \\
Community-supported agriculture (CSA) & 4 & 122 \\
\hline
\end{tabular}

alpha values for satisfaction with current performance and expectations regarding future performance are all larger than 0.80 and AVE for both are larger than 0.600.

While tests to assess scale reliability, such as Cronbach alpha, show that the scale has adequate internal consistency, it is also important that the degree of overlap among scales is not an issue. Discriminant validity tests assure the researcher that different scales actually measure different factors (Bryant 2000). According to Fornell and Larcker (1981), measurement scales exhibit discriminant validity when the square root of AVE is greater than the correlation between scales. As seen in Table 6, the correlation between measurement scales is always less than the square root of the AVE shown on the diagonal. Given these results, we proceed to the path analysis.

To analyse the relationships between the firm's market orientation, entrepreneurial orientation, and firm performance, we develop a PLS-SEM using SmartPLS 3.0 (Ringle et al. 2015). Management scholars who wish to model interactions between latent constructs when data may not be normal and when sample sizes may be small have used PLS-SEM (Hulland 1999; Hair et al. 2011). PLS-SEM has been used extensively in the literature to examine the relationships between latent constructs and various measures of performance (e.g. Hair et al. 2012; Ashok et al. 2016; Lee et al. 2016). Structural equation modelling (SEM) is a statistical method that enables researchers to measure

Table 5 Descriptive statistics of innovation variables and control variables

\begin{tabular}{|c|c|c|c|}
\hline \multirow[t]{2}{*}{ Variable } & \multicolumn{3}{|c|}{ Innovation activity reported by respondents } \\
\hline & Not at all & To some extent & To a large extent \\
\hline \multicolumn{4}{|l|}{ Product innovation (new to farm) } \\
\hline New or significantly improved processed product & $54(42.9 \%)$ & $25(19.8 \%)$ & $6(4.8 \%)$ \\
\hline New or significantly improved packaging & $54(42.9 \%)$ & $25(19.8 \%)$ & $11(8.7 \%)$ \\
\hline \multicolumn{4}{|l|}{ Marketing innovation (new to farm) } \\
\hline Marketing channel & $51(40.5 \%)$ & $36(28.6 \%)$ & $15(11.9 \%)$ \\
\hline \multirow[t]{2}{*}{ Communications, advertising, or promotion methods } & $47(37.3 \%)$ & $43(34.1 \%)$ & $18(14.3 \%)$ \\
\hline & Median & Minimum & Maximum \\
\hline Farming experience (years) & 23.00 & 3.00 & 55.00 \\
\hline Farm gross sales (categorical) ${ }^{b}$ & 4.00 & 2.00 & 8.00 \\
\hline
\end{tabular}

aPercentages are based on sample of 126 and may not sum to 100. Residuals are missing data or 'does not apply' responses, which received a score of zero in innovation index generation

${ }^{\mathrm{b}}$ Categorical variable where $1=$ less than $\$ 10,000 ; 2=\$ 10,000$ to $\$ 24,999 ; 3=\$ 25,000$ to $\$ 49,999 ; 4=\$ 50,000$ to $\$ 99,999$;

$5=\$ 100,000$ to $\$ 249,999 ; 6=\$ 250,000$ to $\$ 499,999 ; 7=\$ 500,000$ to $\$ 999,999 ;$ and $8=\$ 1$ million and over 


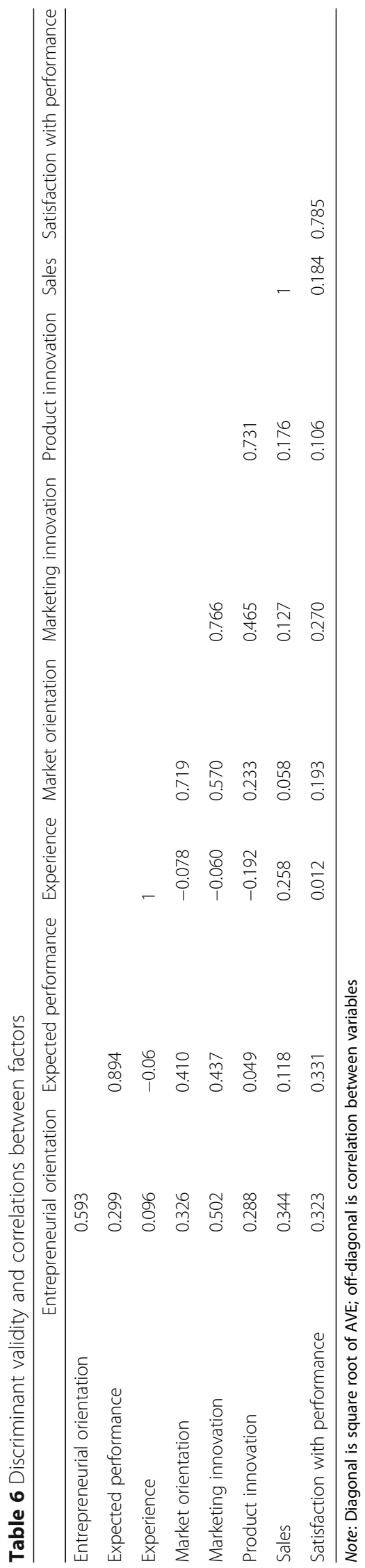


interactions between unobservable variables (such as a market orientation or entrepreneurial orientation) in complex models when data sets are small. Contrary to covariance-based SEM which minimizes the difference in covariance between the actual data and the values predicted by the model, PLS-SEM attempts to maximize the explained variance within latent constructs iteratively using a series of OLS regressions (Hair et al. 2011; Monecke and Leisch 2012).

In addition to the independent variables, we incorporate two variables that we hypothesize will mediate performance: indices of product innovation intensity and of marketing innovation intensity. Control variables beyond farm management experience and gross farm sales as a size proxy have been considered but have not been included in this analysis for practical reasons. ${ }^{4}$ In the analysis, we use satisfaction with current performance and expected performance as dependent variables (and also include a control between current performance and expected performance) that are influenced by the independent variables shown in Fig. 1. The results of the models are presented in Table 7.

Table 7 Results of path analysis

\begin{tabular}{|c|c|c|c|c|c|c|}
\hline & $\begin{array}{l}\text { Path } \\
\text { coefficient }\end{array}$ & $\begin{array}{l}P \\
\text { values }\end{array}$ & $\begin{array}{l}\text { Indirect } \\
\text { effects }\end{array}$ & $\begin{array}{l}P \\
\text { values }\end{array}$ & $\begin{array}{l}\text { Total } \\
\text { effects }\end{array}$ & $\begin{array}{l}P \\
\text { values }\end{array}$ \\
\hline Market orientation $\rightarrow$ marketing innovation & 0.394 & 0.000 & & & 0.394 & 0.000 \\
\hline Market orientation $\rightarrow$ product innovation & 0.136 & 0.116 & & & 0.136 & 0.116 \\
\hline $\begin{array}{l}\text { Market orientation } \rightarrow \text { satisfaction with } \\
\text { performance }\end{array}$ & 0.066 & 0.581 & & & 0.104 & 0.346 \\
\hline Market orientation $\rightarrow$ expected performance & 0.245 & 0.011 & 0.084 & 0.080 & 0.329 & 0.000 \\
\hline $\begin{array}{l}\text { Entrepreneurial orientation } \rightarrow \text { product } \\
\text { innovation }\end{array}$ & 0.182 & 0.079 & & & 0.182 & 0.079 \\
\hline $\begin{array}{l}\text { Entrepreneurial orientation } \rightarrow \text { marketing } \\
\text { innovation }\end{array}$ & 0.283 & 0.000 & & & 0.283 & 0.000 \\
\hline $\begin{array}{l}\text { Entrepreneurial orientation } \rightarrow \text { satisfaction with } \\
\text { performance }\end{array}$ & 0.190 & 0.076 & 0.025 & 0.570 & 0.215 & 0.032 \\
\hline $\begin{array}{l}\text { Entrepreneurial orientation } \rightarrow \text { expected } \\
\text { performance }\end{array}$ & 0.075 & 0.444 & 0.076 & 0.090 & 0.151 & 0.138 \\
\hline $\begin{array}{l}\text { Product innovation } \rightarrow \text { satisfaction with } \\
\text { performance }\end{array}$ & -0.027 & 0.806 & & & -0.027 & 0.806 \\
\hline Product innovation $\rightarrow$ expected performance & -0.128 & 0.166 & & & -0.133 & 0.177 \\
\hline $\begin{array}{l}\text { Marketing innovation } \rightarrow \text { satisfaction with } \\
\text { performance }\end{array}$ & 0.104 & 0.375 & & & 0.104 & 0.375 \\
\hline Marketing innovation $\rightarrow$ expected performance & 0.207 & 0.026 & & & 0.227 & 0.012 \\
\hline $\begin{array}{l}\text { Satisfaction with performance } \rightarrow \text { expected } \\
\text { performance }\end{array}$ & 0.188 & 0.066 & & & 0.188 & 0.066 \\
\hline Sales $\rightarrow$ expected performance & 0.058 & 0.489 & & & 0.078 & 0.340 \\
\hline Sales $\rightarrow$ satisfaction with performance & 0.106 & 0.292 & & & 0.106 & 0.292 \\
\hline Experience $\rightarrow$ satisfaction with performance & -0.027 & 0.807 & & & -0.027 & 0.807 \\
\hline \multirow[t]{2}{*}{ Experience $\rightarrow$ expected performance } & -0.073 & 0.331 & & & -0.078 & 0.331 \\
\hline & $R$ square & \multicolumn{2}{|c|}{ Adjusted $R$ square } & & & \\
\hline Expected performance & 0.250 & 0.207 & & & & \\
\hline Marketing innovation & 0.300 & 0.289 & & & & \\
\hline Product innovation & 0.066 & 0.051 & & & & \\
\hline Satisfaction with performance & 0.102 & 0.058 & & & & \\
\hline
\end{tabular}


First, we do find support for hypothesis 1 that market-orientated firms are more likely to engage in market innovations. Our results do not show a significant relationship between a market orientation and product innovation intensity; therefore, hypothesis 2 is not supported. The corresponding coefficients show that an increase in the market orientation scale by one leads to an increased score on the market innovation scale by 0.394 . In regard to the role of entrepreneurial orientation, the results show that it is strongly and positively linked with the intensity of both product and marketing innovations, thus providing support for hypotheses 5 and 6 . It may be worth noting that the significance is much stronger in both cases when examining the relationship with marketing innovations (1\%) compared to product innovations (10\%).

Interestingly, an increase in the market orientation of the firm was not shown to have a direct relationship with current performance (hypothesis 3 not supported), and there was similarly no support found for the relationship between an entrepreneurial orientation and expected performance (hypothesis 8 not supported).

In terms of the effect of innovation intensity on satisfaction with current performance or expected future performance, the results from our model do not show any significant effects of product innovation intensity on either performance measure. However, our results do show that the intensity of marketing innovations undertaken over the past 3 years has a positive association with expectations of future performance (H10b supported).

Analysis of indirect and total effects within the bootstrapped estimates shows instances where innovation intensity mediates the relationships between the latent constructs. Significant indirect (and total) effects are seen in paths that link market orientation and expected future performance (through product innovation intensity, market innovation intensity, and satisfaction with performance). In addition, there is a significant (albeit small) indirect effect between an entrepreneurial orientation and satisfaction with current performance levels.

The ability of the model to explain satisfaction with current performance is rather limited as the $r$-squared is 0.102 , compared to the corresponding value of 0.25 for expected future performance. This difference between the two models could be traced back to the coefficients for testing hypotheses $3,7,9 a$, and 10a, the paths from managerial orientations and innovation intensities to the respective indicator of firm performance. In those four paths, only the path from the firm's entrepreneurial orientation to satisfaction with current performance was significant at the $10 \%$ level. However, for expected future performance, positive and highly significant coefficients can be reported. Increases in market orientation lead to higher expected performance $(\beta=0.245)$ supporting hypothesis 4 , as does increased engagement in marketing innovation $(\beta=0.207)$, thus supporting hypothesis $10 \mathrm{~b}$. These marketing-related paths are further strengthened by the positive correlation between market orientation and marketing innovation intensity (hypothesis 1 ). Hypothesis 8 , which posits that an entrepreneurial orientation is positively correlated with expected performance, is not supported by our analysis.

\section{Managerial implications}

The following key findings of our analysis are particularly relevant for an accurate discussion of managerial implications. First, market orientation and entrepreneurial 
orientation have been found to be distinct constructs. Both are directly linked to innovation intensity and to different measures of performance. However, without further investigation of the paths to farm performance, these observations would be of mere descriptive value. So building on the first key result, the second one is that both market orientation and entrepreneurial orientation are indirectly-through innovation decisions-related to expected performance. The ability to identify these extended paths of indirect effects is one of the major advantages of the chosen approach of structural equation modelling. Although entrepreneurial orientation is positively related to both product and marketing innovation intensity, its impact is stronger on the latter. Additionally, we find that the effect of a market orientation is more strongly associated with the intensity of marketing innovations.

The stronger relationship between these orientations and market innovation intensity (rather than product innovation intensity) may reflect the findings of Levinthal and March (1993) who suggest that the returns to exploitation may be greater than the returns to exploration for certain firms. One might posit that marketing a current product in a different channel would constitute exploitative search as this requires the firm to continue producing current offerings while searching for new markets in which to sell them. The skills required to be successful in this search may be very different (and more easy to obtain) than the skills required to identify and iterate new product development strategies. This may echo the uncertainty of success that many firms face when developing product-focused innovations (Evanschitzky et al. 2012). Furthermore, as many of the firms used in our study have few employees relative to established food processing firms, the level of human and organizational capital devoted to new product development may be lower, which may lead to a lower success rate and therefore lower expectations of future performance. Another explanation of this result could be that product and packaging innovation may require major investments that present a particular financial burden in the first years after the investment.

But even so, the path with positive and highly significant effects from market orientation to expected performance directly-as well as indirectly through marketing innovation intensity-is striking as it suggests that firms who are aware of customer demands and competitor actions expect significant benefits from marketing-focused innovations. Similarly, our result that increasing market orientation but not entrepreneurial orientation was directly linked to higher expected performance may indicate that more market-oriented firms have more options and flexibility or possibly also more confidence to adapt to market changes to stay profitable. Without these capacities, investments in product-related innovations are also at higher risk of underperforming or even failing. Our survey did not cover how these skills and capacities were or could be obtained, but we would expect that farm operators will increasingly express demand for corresponding learning opportunities and specialized services in these areas.

Finally, although product and marketing innovations are not the only possible paths to increased performance, they are by far the most relevant in the context of direct-toconsumer and alternative marketing approaches. Further, our results corroborate findings of previous research across different industries, as we show that more market-oriented and more entrepreneurial firms have higher levels of expected performance 
than their rivals (Wiklund and Shepherd 2003; Narver et al. 2004; Verhees and Meulenberg 2004; Beck et al. 2011). The key contribution beyond these previous findings is, however, that a positive impact of entrepreneurial orientation on performance hinges on the firm's market orientation. This is likely a unique characteristic of the relatively small direct-to-consumer and alternative marketing industry in agriculture.

\section{Conclusions}

Using a PLS-SEM applied to data from a 2013 survey of direct marketers in Ontario, Canada, this paper examines the importance of a market orientation and entrepreneurial orientation for farm operations. These results show that market awareness coupled with a timely response is an important factor in improving expected future performance.

One of the limitations of this study is that it relies on self-reported and subjective measures of current and future performance. The use of self-reported subjective measures may not have been avoidable since the subjects of inquiry are closely held farm operations. Therefore, the results should be interpreted with caution, especially when it comes to suggesting causal links between entrepreneurial traits, innovation activity, and satisfaction with current performance or expectations of future performance. This also applies to the fact that the data are cross-sectional in nature, as it relies on data from one point in time. Additionally, this study examines the results of marketing and product innovation strategies in Ontario, Canada; therefore, the applicability to other areas may be limited. However, we feel that the results of this research could provide firms in similar political, technological, social, and economic situations a framework from which to build a strategy to compete within direct and alternative markets. Future research in this area could develop new tools and methods to overcome these limitations, either by developing a panel dataset or by establishing the relationship between subjective and objective measures of performance within this sector.

Bearing these limitations in mind, the following general results are highlighted. First, an entrepreneurial orientation has been found to be positively associated with both product and marketing innovation intensity, which suggests that proactive and innovative firms are more likely to engage in new product development or implement changes in how products are marketed. We also find that a market orientation is positively associated with product and marketing innovation. This finding provides broader support for the link between marketing capabilities and innovation among SMEs (Banterle et al. 2011) by finding a similar linkage with respect to a market orientation to product and marketing innovation within another context. Furthermore, by modelling both a market orientation and an entrepreneurial orientation, we are able to observe how increases in these strategic resources may directly and indirectly influence expectations of future performance. For firms operating in highly competitive markets, developing an entrepreneurial orientation alongside a market orientation may enable the firm to become aware of and seize opportunities in new or rapidly evolving markets such as entomology-based protein chains (Pascucci et al. 2015).

Second, since innovation activity was measured as new-to-the-farm adaptations or changes during the most recent 3 years, no significant link between current farm performance and innovation output was found. However, we did find a link between innovations and expected performance. Specifically, we find more market-oriented 
farms are expecting significant improvements in future performance. This may be a reflection of optimism bias (Meyer 2014), but it also may be the manifestation of a true relationship between awareness of market needs and the firm's ability to meet these needs through changes in their marketing mix.

Fourth and finally, farms with greater entrepreneurial orientation are more likely to develop new products or new packaging for their customers, but there seems to be some uncertainty as to how these innovations are expected to affect performance in the near future. For these farms, focusing on marketing innovations may be a less risky gamble while also making better use of their current capabilities (Carreresi et al. 2015). This may be the result of the necessary skills and capabilities needed to execute the development of a new product line which are less prevalent among small food processing firms relative to the skills and capabilities needed to develop and navigate new marketing channels. Alternatively, it may reflect perceived differences in the risk or real differences in the amortization period of the two types of investment.

As more and more farms utilize direct and alternative markets to sell their products, the development of market-sensing capabilities will become increasingly important. As these markets mature and the novelty of these marketing methods wanes among non-core customers, success within these channels will likely depend on management's ability to identify and react to new and sustainable market trends. In cases such as this, a market orientation would be a valuable resource as it would enable the farm to become aware of opportunities to provide superior value for consumers.

\section{Endnotes}

${ }^{1}$ Seven hundred ninety-nine respondents attempted the survey. One hundred two respondents were found to be ineligible due to size (less than $\$ 10,000$ annual gross sales). Two hundred ninety-two respondents started the survey but did not complete it (for unknown reasons), while 405 completed it.

${ }^{2}$ Since the survey excluded farms with less $\$ 10,000$ annual gross sales, the number of e-mails to eligible recipients must have been considerably smaller than 10,406. Assuming the same share as in those who attempted the survey, i.e. 102 of 799 , or $12.8 \%$, the number of eligible recipients would have been 9078, which would yield a response rate of $4.5 \%$. However, this is likely a lower bound as the link was deactivated by IPSOS Animal Health immediately after 405 completed questionnaires had been received.

${ }^{3}$ The only outlier in AVE is the EO scale, which has an AVE of 0.352 .

${ }^{4}$ For example, the number of perceived direct competitors was elicited in the survey as a measure of fierceness of competition that could impact innovation behaviour. However, the question did not refer specifically to direct and alternative marketing competitors so that when included in the statistical analysis did not improve model fit and had no significant coefficient estimates. Hence, it was dropped from being reported here. Similarly, the main commodity produced can impact innovation activity due to technical and regulatory reasons. However, including this variable was not feasible either because of small numbers for most product groups and because many direct and alternative marketers produce a variety of commodities that have significant contributions to income generation. 


\section{Appendix 1}

Table 8 Items of managerial orientation scales and scale reliabilities

\begin{tabular}{|c|c|c|c|}
\hline Measurement scale & Mean & Std. deviation & Item-to-total correlation \\
\hline \multicolumn{4}{|l|}{ Market orientation $[$ Alpha $=0.938 ;$ AVE $=0.516]$} \\
\hline $\begin{array}{l}\text { The business objectives on our farm operation are driven } \\
\text { by customer satisfaction. }\end{array}$ & 5.28 & 1.598 & 0.627 \\
\hline $\begin{array}{l}\text { We continually monitor our level of commitment to } \\
\text { serving customers' needs. }\end{array}$ & 4.79 & 1.636 & 0.765 \\
\hline $\begin{array}{l}\text { Our strategy for competitive advantage is based on our } \\
\text { understanding of customer needs. }\end{array}$ & 5.19 & 1.484 & 0.756 \\
\hline $\begin{array}{l}\text { Our strategies are driven by our beliefs about how we } \\
\text { can create greater value for our customers. }\end{array}$ & 5.15 & 1.555 & 0.763 \\
\hline We measure customer satisfaction regularly. & 4.98 & 1.762 & 0.744 \\
\hline $\begin{array}{l}\text { We pay close attention to our customers, even after } \\
\text { the sale is made. }\end{array}$ & 5.30 & 1.646 & 0.744 \\
\hline $\begin{array}{l}\text { We share information with our employees concerning } \\
\text { competitors' strategies. }\end{array}$ & 3.98 & 1.852 & 0.592 \\
\hline $\begin{array}{l}\text { We are quick to respond to competitive actions that } \\
\text { threaten us. }\end{array}$ & 4.46 & 1.657 & 0.658 \\
\hline $\begin{array}{l}\text { We target customers and customer groups where we } \\
\text { have, or can develop, a competitive advantage. }\end{array}$ & 4.79 & 1.603 & 0.717 \\
\hline We regularly discuss competitors' strengths and strategies. & 4.17 & 1.756 & 0.619 \\
\hline $\begin{array}{l}\text { We regularly visit current customers to see how our } \\
\text { products and/or services are meeting their needs. }\end{array}$ & 4.39 & 1.859 & 0.741 \\
\hline $\begin{array}{l}\text { We discuss reasons for successful and unsuccessful } \\
\text { customer experiences on a regular basis. }\end{array}$ & 4.72 & 1.652 & 0.817 \\
\hline $\begin{array}{l}\text { We coordinate all of our business functions (from buying } \\
\text { to producing, selling and accounting) in order to better } \\
\text { serve the needs of our target markets. }\end{array}$ & 4.62 & 1.784 & 0.770 \\
\hline $\begin{array}{l}\text { We understand how everyone in our company can } \\
\text { contribute to creating customer value. }\end{array}$ & 5.06 & 1.599 & 0.654 \\
\hline \multicolumn{4}{|l|}{ Entrepreneurial orientation $[\mathrm{Alpha}=0.824 ; \mathrm{AVE}=0.352]$} \\
\hline $\begin{array}{l}\text { A strong emphasis on the use of tried and true products } \\
\text { or services for our farm operation. }\end{array}$ & 3.86 & 1.691 & 0.431 \\
\hline No new lines of products or services. & 3.59 & 1.786 & 0.501 \\
\hline $\begin{array}{l}\text { Changes in product or service lines have been mostly } \\
\text { of a minor nature. }\end{array}$ & 3.41 & 1.790 & 0.553 \\
\hline Typically responds to actions which competitors initiate. & 3.84 & 1.286 & 0.386 \\
\hline $\begin{array}{l}\text { Typically seeks to avoid clashes with competitors, preferring } \\
\text { a live-and-let-live attitude. }\end{array}$ & 3.52 & 1.446 & 0.549 \\
\hline $\begin{array}{l}\text { Tend to focus on low-risk investment projects (with normal } \\
\text { and certain rates of return). }\end{array}$ & 3.26 & 1.476 & 0.658 \\
\hline $\begin{array}{l}\text { Owing to the nature of the business environment, it is best } \\
\text { to explore our options gradually via cautious, incremental } \\
\text { behaviour. }\end{array}$ & 3.25 & 1.440 & 0.664 \\
\hline $\begin{array}{l}\text { Typically adopt a cautious wait and see attitude in order } \\
\text { to minimize the probability of making costly decision. }\end{array}$ & 3.29 & 1.469 & 0.666 \\
\hline
\end{tabular}




\section{Appendix 2}

Table $\mathbf{9}$ Items of performance scales and scale reliabilities

\begin{tabular}{|c|c|c|c|c|c|c|}
\hline & \multicolumn{3}{|c|}{$\begin{array}{l}\text { Current performance } \\
{[\text { Alpha }=0.831 ; \mathrm{AVE}=0.617]}\end{array}$} & \multicolumn{3}{|c|}{$\begin{array}{l}\text { Expected performance }^{\mathrm{b}} \\
{[\text { Alpha }=0.922 ; \mathrm{AVE}=0.799]}\end{array}$} \\
\hline & Mean & Std. deviation & Loading & Mean & Std. deviation & Loading \\
\hline Gross farm sales & 4.16 & 1.54 & 0.620 & 4.91 & 1.22 & 0.961 \\
\hline Net farm income & 3.49 & 1.62 & 0.742 & 4.68 & 1.36 & 0.849 \\
\hline Cash flow & 3.76 & 1.69 & 0.956 & 4.63 & 1.21 & 0.867 \\
\hline
\end{tabular}

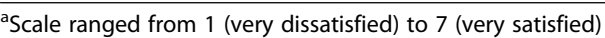

bsale ranged from 1 (will deteriorate significantly) to 7 (will improve significantly)

\section{Funding}

This research was partially funded through a grant from the Structure and Performance of Agriculture and Agri-products Industry Network. Researchers from Agriculture and Agri-Food Canada provided feedback on the survey design but did not participate in the analysis of the data or the interpretation of the results.

\section{Authors' contributions}

EM and AB developed the survey to collect data. EM developed the proposed model and wrote the "Background" and "Methods" sections. AB wrote the "Results and discussion" and the "Conclusions" sections. Both authors read and approved the final manuscript.

\section{Competing interests}

The authors declare that they have no competing interests.

\section{Publisher's Note}

Springer Nature remains neutral with regard to jurisdictional claims in published maps and institutional affiliations.

\section{Author details}

${ }^{1}$ Department of Agricultural and Resource Economics, University of Saskatchewan, 51 Campus Drive, Saskatoon, SK S7N 5A8, Canada. ${ }^{2}$ Department of Food, Agricultural and Resource Economics, University of Guelph, Guelph, ON N1G 2W1, Canada.

Received: 28 December 2015 Accepted: 24 April 2017

Published online: 23 May 2017

\section{References}

Adams DC, Adams AE (2011) De-placing local at the farmers' market: consumer conceptions of local foods. J Rural Soc Sci 26(2):74-100

Ashok M, Narula R, Martinez-Noya A (2016) How do collaboration and investments in knowledge management affect process innovation in services? J Knowl Manag 20:1004-1024. doi:10.1108/JKM-11-2015-0429

Banterle A, Cavaliere A, Carraresi L, Stranieri S (2011) Innovativeness in food small business: what is its relationship with marketing? Agric Econ 57:474-483

Barbieri C, Mahoney E (2009) Why is diversification an attractive farm adjustment strategy? Insights from Texas farmers and ranchers. J Rural Stud 25:58-66. doi:10.1016/j.jrurstud.2008.06.001

Beck L, Janssens W, Debruyne M, Lommelen T (2011) A study of the relationships between generation, market orientation, and innovation in family firms. Fam Bus Rev 24:252-272. doi:10.1177/0894486511409210

Beckie MA, Kennedy EH, Wittman H (2012) Scaling up alternative food networks: farmers' markets and the role of clustering in western Canada. Agric Human Values 29:333-345. doi:10.1007/s10460-012-9359-9

Boehlje M (2002) Risk in U.S. agriculture: new challenges and new approaches

Boehlje M, Bröring S (2011) The increasing multifunctionality of agricultural raw materials: three dilemmas for innovation and adoption. Int Food Agribus Manag Rev 14:1-16

Boehlje M, Akridge J, Downey D (1995) Restructuring agribusiness for the 21st century. Agribusiness 11:493-500 doi:10.1002/1520-6297(199511/12)11:6<493::AID-AGR2720110602>3.0.CO;2-G

Brik AB, Rettab B, Mellahi K (2011) Market orientation, corporate social responsibility, and business performance. J Bus Ethics 99:307-324. doi:10.1007/s10551-010-0658-z

Bryant FB (2000) Assessing the validity of measurement. In: Grimm LG, Yarnold PR (eds) Reading and understanding more multivariate statistics. American Psychological Association, Washington, pp 99-146

Cambra-Fierro J, Florin J, Perez L, Whitelock J (2011) Inter-firm market orientation as antecedent of knowledge transfer, innovation and value creation in networks. Manag Decis 49:444-467. doi:10.1108/00251741111120798

Camisón C, Villar-López A (2011) Non-technical innovation: organizational memory and learning capabilities as antecedent factors with effects on sustained competitive advantage. Ind Mark Manag 40:1294-1304. doi:10.1016/j. indmarman.2011.10.001

Carreresi L, Mamaqi X, Albisu LM, Banterle A (2015) Can strategic capabilities affect performance? Appication of RBV to small food businesses. Agribusiness. doi:10.1002/agr.21451 
Cheng CC, Krumwiede D (2012) The role of service innovation in the market orientation-new service performance linkage. Technovation 32:487-497. doi:10.1016/j.technovation.2012.03.006

Covin JG, Slevin DP (1989) Strategic management of small firms in hostile and benign environments. Strateg Manag J 10:75-87. doi:10.1002/smj.4250100107

Cranfield J, Henson S, Blandon J (2012). The effect of attitudinal and sociodemographic factors on the likelihood of buying locally produced food. Agribusiness, 28(2):205-221

Cronbach LJ (1951) Coefficient alpha and the internal structure of tests. Psychometrica 16:297-334

Cummings H, Kora G, Murray D (1999) Farmers' markets in Ontario and their economic impact

Dawes I (1999) The relationship between subjective and objective company performance measures in market orientation research: further empirical evidence. Mark Bull 10:65-75

de Lauwere CC (2005) The role of agricultural entrepreneurship in Dutch agriculture of today. Agric Econ 33:229-238

Dess GG, Robinson RB Jr (1984) Measuring organizational performance in the absence of objective measures: the case of the privately-held firm and conglomerate business unit. Strateg Manag J 5:265-273

Dewar RD, Dutton JE (1986) The adoption of radical and incremental innovations: an empirical analysis. Manage Sci 32:1422-1433

Di Stefano G, Gambardella A, Verona G (2012) Technology push and demand pull perspectives in innovation studies: current findings and future research directions. Res Policy 41:1283-1295. doi:10.1016/j.respol.2012.03.021

Dodds R, Holmes M, Arunsopha V et al (2013) Consumer choice and farmers' markets. J Agric Environ Ethics 27:397-416. doi:10.1007/s10806-013-9469-4

Dukeshire S, Masakure O, Mendoza J et al. (2014) Understanding consumer choices for Ontario produce. Renew Agric Food Syst :1-11. doi:10.1017/S1742170514000234

Evanschitzky H, Eisend M, Calantone RJ, Jiang Y (2012) Success factors of product innovation: an updated meta-analysis. J Prod Innov Manag 29:21-37. doi:10.1111/j.1540-5885.2012.00964.x

Farrell MA, Oczkowski E, Kharabsheh R (2008) Market orientation, learning orientation and organisational performance in international joint ventures. Asia Pacific J Mark Logist 20:289-308. doi:10.1108/13555850810890066

Feldmann C, Hamm U (2015). Consumers' perceptions and preferences for local food: A review. Food Quality and Preference, 40:152-164

Fornell C, Larcker DF (1981) Evaluating structural equation models with unobservable variables and measurement error. J Mark Res 18:39-50, doi: http://dx.doi.org/10.2307/3151312

Garcia R, Calantone R (2002) A critical look at technological innovation typology and innovativeness terminology: a literature review. J Prod Innov Manag 19:110-132

Gellynck X, Banterle A, Kühne B et al (2012) Market orientation and marketing management of traditional food producers in the EU. Br Food J 114:481-499. doi:10.1108/00070701211219513

Gracia A (2012) Importance of social influence in consumers' willingness to pay for local food: are there gender differences? Agribusiness 28:361-371. doi:10.1002/agr

Grande J, Madsen EL, Borch OJ (2011) The relationship between resources, entrepreneurial orientation and performance in farm-based ventures. Entrep Reg Dev An Int J 23:89-111. doi:10.1080/08985620903183710

Gunday G, Ulusoy G, Kilic K, Alpkan L (2011) Effects of innovation types on firm performance. Int J Prod Econ 133:662-676. doi:10.1016/j.jpe.2011.05.014

Guthrie J, Guthrie A, Lawson R, Cameron A (2006) Farmers' markets: the small business counter-revolution in food production and retailing. Br Food J 108:560-573. doi:10.1108/00070700610676370

Hair JF, Ringle CM, Sarstedt M (2011) PLS-SEM: indeed a silver bullet. J Mark Theory Pract 19:139-152. doi:10.2753/ MTP1069-6679190202

Hair JF, Sarstedt M, Pieper TM, Ringle CM (2012) The use of partial least squares structural equation modeling in strategic management research: a review of past practices and recommendations for future applications. Long Range Plann 45:320-340. doi:10.1016/j.lrp.2012.09.008

Han JK, Kim N, Srivastava RK (1998) Market orientation and organizational performance: is innovation a missing link? J Mark 62:30-35, doi: http://dx.doi.org/10.2307/1252285

Hansen JD, Deitz GD, Tokman M et al (2011) Cross-national invariance of the entrepreneurial orientation scale. J Bus Ventur 26:61-78. doi:10.1016/j.jbusvent.2009.05.003

Hong J, Song TH, Yoo S (2013) Paths to success: how do market orientation and entrepreneurship orientation produce new product success? J Prod Innov Manag 30:44-55. doi:10.1111/j.1540-5885.2012.00985.x

Hu W, Batte MT, Woods T, Ernst S (2012) Consumer preferences for local production and other value-added label claims for a processed food product. Eur Rev Agric Econ 39:489-510. doi:10.1093/erae/jbr039

Hulland J (1999) Use of partial least squares (PLS) in strategic management research: a review of four recent studies. Strateg Manag J 20:195-204. doi:10.2307/3094025

Keh HT, Nguyen TTM, Ng HP (2007) The effects of entrepreneurial orientation and marketing information on the performance of SMEs. J Bus Ventur 22:592-611. doi:10.1016/j.jbusvent.2006.05.003

Kim M, Curtis KR, Yeager I (2014) An assessment of market strategies for small-scale produce growers. Int Food Agribus Manag Rev 17:187-204

Knudson W, Wysocki A, Champagne J, Peterson HC (2004) Entrepreneurship and innovation in the agri-food system. Am J Agric Econ 86:1330-1336

Köhler C, Sofka W, Grimpe C (2012) Selective search, sectoral patterns, and the impact on product innovation performance. Res Policy 41:1344-1356. doi:10.1016/j.respol.2012.03.020

Lambrecht E, Taragola N, Kühne B et al (2015) Networking and innovation within the ornamental plant sector. Agric Food Econ 3:1-20. doi:10.1186/s40100-014-0022-1

Lamore PR, Berkowitz D, Farrington PA (2013) Proactive/responsive market orientation and marketing - research and development integration. J Prod Innov Manag 30:695-711. doi:10.1111/jpim.12024

Langerak F (2003) The effect of market orientation on positional advantage and organizational performance. J Strateg Mark 11:93-115

Lee RP, Zhou KZ (2012) Is product imitation good for firm performance? An examination of product imitation types and contingency factors. J Int Mark 20:1-16. doi:10.1509/jim.12.0019 
Lee H, Smith KG, Grimm CM, Schomburg A (2000) Timing, order and durability of new product advantages with imitation. Strateg Manag J 21:23-30. doi:10.1002/(SICI)1097-0266(200001)21:1<23:AID-SMJ64>3.0.CO;2-0

Lee C, Hallak R, Sardeshmukh SR (2016) Innovation, entrepreneurship, and restaurant performance: a higher-order structural model. Tour Manag 53:215-228. doi:10.1016/j.tourman.2015.09.017

Levinthal DA, March JG (1993) The myopia of learning. Strateg Manag J 14:95-112. doi:10.1002/smj.4250141009

Li Y-H, Huang J-W, Tsai M-T (2009) Entrepreneurial orientation and firm performance: the role of knowledge creation process. Ind Mark Manag 38:440-449. doi:10.1016/j.indmarman.2008.02.004

Low SA, Vogel S (2011) Direct and intermediated marketing of local foods in the United States

Lumpkin GT, Dess GG (1996) Clarifying the entrepreneurial orientation construct and linking it to performance. Acad Manag Rev 21:135-172

Lumpkin GT, Dess GG (2001) Linking two dimensions of entrepreneurial orientation to firm performance: the moderating role of environment and industry life cycle. J Bus Ventur 16:429-451. doi:10.1016/50883-9026(00)00048-3

Mahto RV, Davis PS, Pearce JA, Robinson RB (2010) Satisfaction with firm performance in family businesses. Entrep Theory Pract 34:985-1001. doi:10.1111/j.1540-6520.2010.00393.x

Mirzaei OM, Micheels ET, Boecker A (2016). Product and Marketing Innovation in Farm-Based Businesses: The Role of Entrepreneurial Orientation and Market Orientation. International Food and Agribusiness Management Review, 19(2):99-130

Meyer WG (2014) The effect of optimism bias on the decision to terminate failing projects. Proj Manag J 45:7-20. doi:10.1002/pmj

Monecke A, Leisch F (2012) semPLS: structural equation modeling using partial least squares. J Stat Softw 48:1-32

Moreno AM, Casillas JC (2008) Entrepreneurial orientation and growth of SMEs: a causal model. Entrep Theory Pract 32:507-528

Moser R, Raffaelli R, Thilmany-McFadden D (2011) Consumer preferences for fruit and vegetables with credence-based attributes: a review. Int Food Agribus Manag Rev 14:121-142

Mount P (2012) Growing local food: scale and local food systems governance. Agric Human Values 29:107-121. doi:10.1007/s10460-011-9331-0

Nadella K, Deaton B, Lawley C, Weersink A (2014) Do farmers treat rented land differently than the land they own? A fixed effects model of farmer's decision to adopt conservation practices on owned and rented land. In: Agricultural \& Applied Economics Association's 2014 AAEA Annual Meeting., pp 1-17

Narver JC, Slater SF (1990) The effect of a market orientation on business profitability. J Mark 54:20-35, doi: http://dx. doi.org/10.2307/1251757

Narver JC, Slater SF, Maclachlan DL (2004) Responsive and proactive market orientation and new-product success. J Prod Innov Manag 21:334-347. doi:10.1111/j.0737-6782.2004.00086.x

Nasution HN, Mavondo FT, Matanda MJ, Ndubisi NO (2011) Entrepreneurship: its relationship with market orientation and learning orientation and as antecedents to innovation and customer value. Ind Mark Manag 40:336-345. doi: 10.1016/j.indmarman.2010.08.002

Nelson RR, Winter SG (1982) An evolutionary theory of economic change. Harvard University Press, Boston

Ngo LV, O'Cass A (2012) In search of innovation and customer-related performance superiority: the role of market orientation, marketing capability, and innovation capability interactions. J Prod Innov Manag 29:861-877. doi:10.1111/j.1540-5885.2012.00939.x

OMAFRA (2014). Number of Ontario Census Farms Classified by Total Gross Farm Receipts, 2006 and 2011. http://www. omafra.gov.on.ca/english/stats/census/receipts 11. htm

Pascucci S, Dentoni D, Mitsopoulos D (2015) The perfect storm of business venturing? The case of entomology-based venture creation. Agric Food Econ. doi:10.1186/s40100-014-0025-y

Pérez-Luño A, Wiklund J, Cabrera RV (2011) The dual nature of innovative activity: how entrepreneurial orientation influences innovation generation and adoption. J Bus Ventur 26:555-571. doi:10.1016/j.jbusvent.2010.03.001

Rauch A, Wiklund J, Lumpkin GT, Frese M (2009) Entrepreneurial orientation and business performance: an assessment of past research and suggestions for the future. Entrep Theory Pract 33:761-787

Regional Analytics and Planscape (2011) Economic impacts of farmers' markets in the province of Ontario

Renko M, Carsrud A, Brännback M (2009) The effect of a market orientation, entrepreneurial orientation, and technological capability on innovativeness: a study of young biotechnology ventures in the United States and in Scandinavia. J Small Bus Manag 47:331-369

Rhee J, Park T, Lee DH (2010) Drivers of innovativeness and performance for innovative SMEs in South Korea: mediation of learning orientation. Technovation 30:65-75. doi:10.1016/j.technovation.2009.04.008

Richard PJ, Devinney TM, Yip GS, Johnson G (2009) Measuring organizational performance: towards methodological best practice. J Manage 35:718-804. doi:10.1177/0149206308330560

Ringle CM, Wende S, Becker J-M (2015) SmartPLS 3

Rosenbusch N, Brinckmann J, Bausch A (2011) Is innovation always beneficial? A meta-analysis of the relationship between innovation and performance in SMEs. J Bus Ventur 26:441-457. doi:10.1016/j.jbusvent.2009.12.002

Roucan-Kane M, Gray AW, Boehlje MD (2011) Approaches for selecting product innovation projects in U.S. food and agribusiness companies. Int Food Agribus Manag Rev 14:51-68

Rowley J, Baregheh A, Sambrook S (2011) Towards an innovation-type mapping tool. Manag Decis 49:73-86. doi:10.1108/00251741111094446

Schumilas T (2010) The feeders meet the eaters-direct marketing in Ontario's organic sector

Shoemaker PJ, Eichholz M, Skewes EA (2002) Item nonresponse: distinguishing between don't know and refuse. Int J Public Opin Res 14:193-201

Slater SF, Narver JC (1995) Market orientation and the learning organization. J Mark 59:63-74, doi: http://dx.doi.org/10. $2307 / 1252120$

Slater SF, Narver JC (2000) Intelligence generation and superior customer value. J Acad Mark Sci 28:120-127

Song M, Thieme J (2009) The role of suppliers in market intelligence gathering for radical and incremental innovation. J Prod Innov Manag 26:43-57. doi:10.1111/j.1540-5885.2009.00333.x 
Sun L, Gómez Ml, Chaddad FR, Ross RB (2014) Distribution channel choices of wineries in emerging cool climate regions. Agric Resour Econ Rev 43:87-103

Tajeddini K (2010) Effect of customer orientation and entrepreneurial orientation on innovativeness: evidence from the hotel industry in Switzerland. Tour Manag 31:221-231. doi:10.1016/j.tourman.2009.02.013

Tajeddini K, Trueman M, Larsen G (2006) Examining the effect of market orientation on innovativeness. J Mark Manag 22:529-551. doi:10.1362/026725706777978640

Tan M, Liu Z (2014) Paths to success: an ambidexterity perspective on how responsive and proactive market orientations affect SMEs' business performance. J Strateg Mark :1-22. doi:10.1080/0965254X.2013.876084

Thilmany D, Bond CA, Bond JK, (2008). Going local: Exploring consumer behavior and motivations for direct food purchases. American Journal of Agricultural Economics, 90(5):1303-1309

Trienekens J, van Uffelen R, Debaire J, Omta O (2008) Assessment of innovation and performance in the fruit chain: the innovation-performance matrix. Br Food J 110:98-127. doi:10.1108/00070700810844812

Uematsu H, Mishra AK (2011) Use of direct marketing strategies by farmers and their impact on farm business income. Agric Resour Econ Rev 40:1-19

Verhees FJHM, Meulenberg MTG (2004) Market orientation, innovativeness, product innovation, and performance in small firms. J Small Bus Manag 42:134-154, doi: http://dx.doi.org/10.1111/j.1540-627X.2004.00102.x

Wall TD, Michie J, Patterson M et al (2004) On the validity of subjective measures of company performance. Pers Psychol 57:95-118. doi:10.1111/j.1744-6570.2004.tb02485.x

Wang CL (2008) Entrepreneurial orientation, learning orientation, and firm performance. Entrep Theory Pract 44:635-657

Weatherell C, Tregear A, Allinson J (2003) In search of the concerned consumer: UK public perceptions of food, farming and buying local. J Rural Stud 19:233-244

Webb JW, Ireland RD, Hitt MA et al (2010) Where is the opportunity without the customer? An integration of marketing activities, the entrepreneurship process, and institutional theory. J Acad Mark Sci 39:537-554. doi:10.1007/s11747-010-0237-y

Wiklund J (1999) The sustainability of the entrepreneurial orientation-performance relationship. Entrep Theory Pract 24:37-48

Wiklund J, Shepherd D (2003) Knowledge-based resources, entrepreneurial orientation, and the performance of small and medium-sized businesses. Strateg Manag J 24:1307-1314. doi:10.1002/smj.360

Wiklund J, Shepherd D (2005) Entrepreneurial orientation and small business performance: a configurational approach. J Bus Ventur 20:71-91. doi:10.1016/j.jbusvent.2004.01.001

Yannopoulos P, Auh S, Menguc B (2012) Achieving fit between learning and market orientation: implications for new product performance. J Prod Innov Manag 29:531-545. doi:10.1111/j.1540-5885.2012.00923.x

Submit your manuscript to a SpringerOpen ${ }^{\circ}$ journal and benefit from:

- Convenient online submission

- Rigorous peer review

- Immediate publication on acceptance

- Open access: articles freely available online

- High visibility within the field

Retaining the copyright to your article

Submit your next manuscript at $\boldsymbol{\sim}$ springeropen.com 